\title{
Spatial modeling of rangeland potential vegetation environments
}

\author{
MARK E. JENSEN, JEFF P. DIBENEDETTO, JAMES A. BARBER, CLIFF MONTAGNE, AND PATRICK S. \\ BOURGERON
}

Authors are ecologist, USDA, Forest Service, Northern Region, Missoula, Mont. 59807; ecologist, USDA, Forest Service, Custer National Forest, Billings, Mont. 59105; ecologist, USDA Forest Service, Northern Region, Missoula, Mont. 59807; associate professor, Land and Environmental Science, Montana State University, Bozeman, Mont. 59715; and research associate, Institute for Arctic and Alpine Research, University of Colorado, Boulder, Colo. 80309-0450.

\begin{abstract}
Potential vegetation environments (e.g., habitat types, range sites, ecological sites) are important to land managers because they provide a conceptual basis for the description of resource potentials and ecological integrity. Efficient use of potential vegetation classifications in regional or subregional scale assessments of ecosystem health has been limited to date, however, because traditional ecological unit mapping procedures often treat such classifications as ancillary information in the map unit description. Accordingly, it is difficult, if not impossible, to describe the precise location, patch size, and spatial arrangement of potential vegetation environments from most traditional ecological unit maps. Recent advances in remote sensing, geographic information systems (GIS), terrain modeling, and climate interpolation facilitate the direct mapping of potential vegetation through a predictive process based on gradient analysis and ecological niche theory. In this paper, we describe how a predictive vegetation mapping process was used to develop a $30 \mathrm{~m}$ raster-based map of 4 grassland, 5 shrubland, and 6 woodland habitat types across the Little Missouri National Grasslands, North Dakota. Discriminant analysis was used in developing this potential vegetation map based on 6 primary geographic information system themes. Geoclimatic subsections and remotely sensed vegetation lifeform maps were used in predictive model stratification. Terrain indices, LANDSAT satellite imagery, and interpolated climate information were used as independent (predictor) variables in model construction. A total of 616 field plots with known habitat type membership were used as dependent variables and assessed by a jackknife discriminant analysis procedure. Accuracy values of our map ranged from 54 to $77 \%$ in grasslands, 62 to $100 \%$ in shrublands, and 70 to $100 \%$ in woodlands dependent on geoclimatic subsection setting. Techniques are also described for generalizing the $30 \mathrm{~m}$ pixel resolution habitat type map to appropriate ecological unit maps (e.g., landtype associations) for use in ecosystem health assessments and land use planning.
\end{abstract}

Primary funding for this research was provided by USDA, Forest Service, Washington Office, Ecosystem Management Staff; USDA, Forest Service, Northern Region; U.S. Environmental Protection Agency, National Exposure Research Laboratory, Environmental Sciences Division; and USDA, Facilitation of this research was provided by USDA, Forest Service, PNW Sation, Wenatchee Forestry Sciences Lab. Natural Resources Conservation Service, Washington Office, Strategic Planning Staff. The authors extend their appreciation and gratitude to John Caratti, Tim McGarvey, and Greg Enstrom for their assistance in database and spatial analysis, and Melissa Hart and Judy Tripp for their assistance in technical editing.

Manuscript accepted 4 Nov. 2000.

\section{Resumen}

Los ambientes de vegetación potencial (por ejemplo, tipos de hábitat, sitios de pastizal, sitios ecológicos) son importantes para el manejador de terrenos porque ellos proveen una base conceptual para la descripción de los recursos potenciales y la integridad ecológica. A la fecha, el uso eficiente de clasificaciones de vegetación potencial en evaluaciones de la salud del ecosistema a escala regional y subregional ha sido limitado, esto debido a que los procedimientos tradicionales de mapeo de unidades ecológicas a menudo tratan tales clasificaciones como información secundaria en la descripción de la unidad de mapeo. De acuerdo a esto, es difícil, si no imposible, describir la localidad precisa, el tamaño de parche y el arreglo espacial de los ambientes de vegetación potencial a partir de los mapas mas tradicionales de unidad ecológica. Avances recientes en el área de sensores remotos, sistemas de información geográfica, modelaje de terreno e interpolación de clima facilitan el mapeo directo de la vegetación potencial a través de un proceso predictivo basado en el análisis de gradientes y la teoría ecológica de nichos. En este articulo describimos como un proceso predictivo de mapeo de vegetación fue usado para desarrollar un mapa raster de $30 \mathrm{~m}$ de tipos hábitat de 4 zacatales, 5 matorrales y 6 bosques a través de los pastizales nacionales de "Little Missouri"de North Dakota. Se uso análisis discriminante en el desarrollo de este mapa de vegetación potencial basado en 6 temas primarios de sistemas de información geográfica. En el modelo de estratificación predictiva se utilizaron subsecciones geoclimáticas y mapas de formas de vida derivados de vegetación procesada con sensores remotos. Indices de terreno, imagen satelital LANDSAT e información climática interpolada se utilizaron en el modelo como variables independientes (predictivas). Se usaron un total de 616 parcelas de campo con tipo de hábitat conocido como variables dependientes y evaluadas por procedimiento de un análisis discriminate de navaja. Los valores de certeza de nuestro mapa variaron de 54 a $77 \%$ en los zacatales, de 62 a $100 \%$ en los matorrales y de 70 a $100 \%$ en los bosques, dependiendo de la subsección geoclimáticas en la que se encontraban situados. También se describen las técnica para generalizar los mapas de tipo de hábitat de resolución de $30 \mathrm{~m}$ por pixel a mapas apropiados de unidades ecológicas (por ejemplo, asociaciones de tipo de terreno) para el uso en las evaluaciones de salud del pastizal y la planeación del uso de la tierra.

Key Words: habitat types, ecological sites, range sites, ecological classification, Geographic Information System, remote sensing, vegetation mapping, ecological units 
Potential vegetation classifications such as ecological sites (RISC 1983), ecological types (USDA, FS 1991) and range sites (Shiflet 1973) are commonly used by land management agencies as a framework for organizing natural resource information, and also as a tool for communicating "natural" baseline conditions for ecosystem health assessments, predictions of vegetation response to management, and resource value potentials. Most potential vegetation classifications utilize indicator plant species to describe environments with similar responses to management. Habitat type (Daubenmire 1968, Pfister et al. 1977, Mueggler and Stewart 1980, Hironaka et al. 1983, Jensen et al. 1988) is an example of a potential vegetation classification system that is widely used by various U.S. land management agencies because relatively few diagnostic species are required to determine a site's ecological potential. In developing habitat type classifications, minimally disturbed, late seral or "climax" plant communities are sampled to determine which combinations of plant species indicate unique environments for management (Pfister et al. 1977). These classifications are, in turn, contrasted with various abiotic components of sampled sites (e.g., soil properties, climate, and geology) to facilitate a better understanding of the complex environments that a habitat type actually represents (Jensen et al. 1990).

Hierarchical ecological unit maps are often used as a basis for the spatial description of potential vegetation (Bailey et al. 1994, Cleland et al. 1997). For example, in the USDA, Forest Service ECOMAP hierarchy (Cleland et al. 1997), the composition of potential vegetation environments is commonly included as ancillary information in the ecological map unit description. Each ecological mapping unit often contains more than 1 dominant potential vegetation type, depending on classification level and mapping scale; hence, this approach commonly does not provide adequate spatial representation of potential vegetation (e.g., patch size, shape, and connectivity) for many land use planning objectives. Consequently, new approaches for directly mapping potential vegetation are now required in most assessments of ecosystem health.

Recent advances in remote sensing, terrain modeling, climate interpolation, and geographic information systems software facilitate such direct mapping of potential vegetation by a process commonly referred to as "predictive vegetation mapping" (Franklin 1995). In this approach, potential vegetation environments are modeled based on mapped environmental variables that are considered to influence vegetation pattern, whether directly or indirectly (Austin and Smith 1989). Predictive vegetation mapping is founded in ecological niche theory and vegetation gradient analysis; it is based on the premises that vegetation distribution can be predicted from the spatial distribution of environmental variables that correlate with or control plant distributions (Franklin 1995).

The primary objective of this paper is to develop a habitat type map using a predictive vegetation mapping process for the Little Missouri National Grasslands of North Dakota. A secondary objective is to illustrate how raster-based maps of potential vegetation (and associated information) can be effectively generalized from $30 \mathrm{~m}$ cells to appropriate ecological unit maps, and subsequently used in ecosystem health assessments and land use planning.

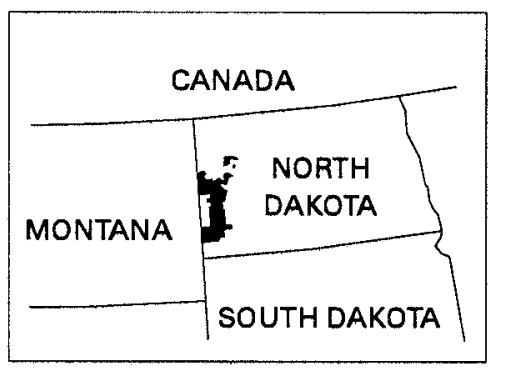

\section{Subsections}
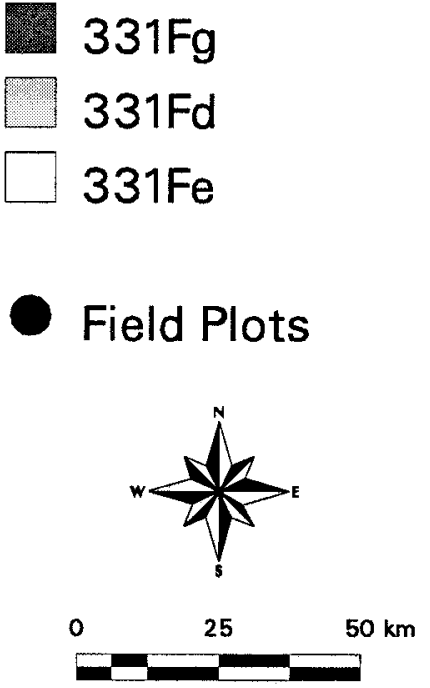

Fig. 1. The study area stratified by geoclimatic subsections and field plots used in describing known habitat type locations within the Little Missouri National Grasslands.

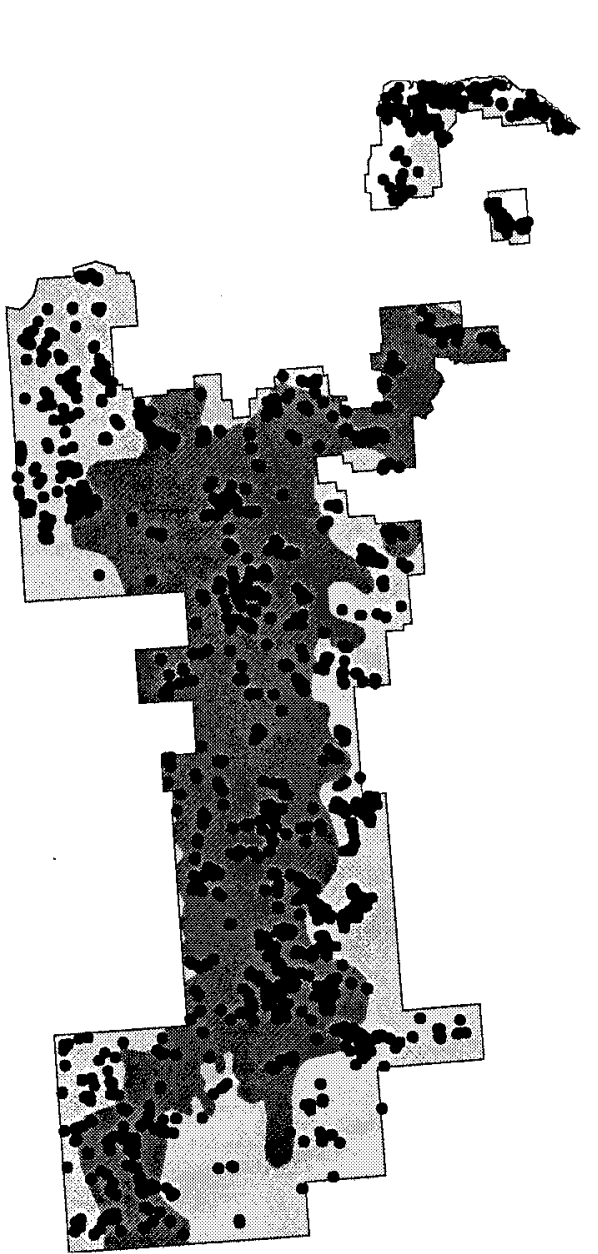

\section{Study area}

This study was conducted within the Little Missouri National Grasslands (hereafter referred to as the Grasslands) of western North Dakota (Lat. $47^{\circ} 15^{\prime} \mathrm{N}$, Long. $103^{\circ} 30^{\prime} \mathrm{W}$ ), an area of approximately 809,380 ha that is managed primarily by the USDA, Forest Service, for cattle grazing, oil and gas leasing, wildlife habitat, and recreation uses (Fig. 1). These grasslands encompass an area of diverse terrain and vegetation pattern and include 3 subsections (Nesser et al. 1997) of the Northern Great Plains Section (Bailey 1995). The Missouri Plateau Subsection (331 Fd) is characterized by rolling plains, fans, and terraces formed in mixed sedimentary alluvium. Steep to very steep hills, deeply entrenched drainageways, and narrow to wide valley bottom settings formed in residual and alluvial sedimentary materials characterize the Little 
Missouri Badlands (331Fg). The Missouri Breaks Subsection $(331 \mathrm{Fe})$ is characterized by rolling hills, river breaks, terraces and floodplains that formed in alluvium, sedimentary rock, and glacial till materials. Dominant soil great groups (Soil Survey Staff 1975) of the study area include: Haploborolls, Argiborolls, Argiustolls, Natrustolls and Ustorthents (Whitman 1978, Nesser et al. 1997).

The climate of the Grasslands is continental and semi-arid (characterized by hot summers and cold winters). Elevations range from about $350 \mathrm{~m}$ along river bottoms to $1,070 \mathrm{~m}$ within the Badlands. Precipitation fluctuates annually and seasonally with over $70 \%$ occurring between April and September (Whitman 1978). A moisture-temperature gradient exists across the study area from the SW to the NE corners. Along this gradient, average annual precipitation increases from 360 to $410 \mathrm{~mm}$; average annual temperature decreases by $1^{\circ} \mathrm{C}$, and the frost free period decreases from 135 to 115 days. A more detailed description of geoclimatic settings within the study area has been developed by the Custer National Forest at the landtype association level (Cleland et al. 1997).

Vegetation of the study area is typical of the mixed grass prairie in the Northern Great Plains. Kuchler (1964) characterized the potential vegetation of this area as a wheatgrass-needlegrass (Agropyron-Stipa) association. Dominant species include western wheatgrass (Agropyron smithii (Rydb.)), green needlegrass (Stipa viridula (Trin.)), needle and thread grass (Stipa comata (Trin. \& Rupr.)), blue grama (Bouteloua gracilis (H.B.K.) Lag.) and threadleaf sedge (Carex filifolia (Nutt.). Little bluestem (Andropogon scoparius (Michx.)) and prairie sandreed (Calamovilfa longifolia (Hook.)) also occur and commonly occupy micro-sites on short slopes and sandy areas, respectively. Various broadleaf and coniferous tree species and shrubs are found on steep north-facing slopes, narrow drainages and draws, and in wide valleys along streams and rivers.

\section{Characterization of field plots}

A total of 616 field plots were used to map and describe habitat types in this study (Fig. 1). These plots were sampled by Custer National Forest personnel between 1987 and 1996 for a variety of objectives including: resource inventories, habitat type and seral plant community classification efforts, and ground truth sampling associated with existing vegetation and land cover satellite imagery map- ping. Despite the fact that these plots were obtained for different objectives, they all followed standardized field sampling procedures as outlined in the Ecological Inventory and Analysis Guide of USDA, Forest Service, Northern Region (USDAFS 1988). This facilitated consistent use of field plot data in subsequent analyses. Sampling protocols associated with these field plots are briefly described below.

Field plots were 0.04 ha size and were subjectively located without preconceived bias (Mueller-Dombois and Ellenberg 1974) on representative habitat type settings across the study area (i.e., plots were randomly placed within clearly delineated habitat types). Data collected at each plot included: soil morphology, elevation, geology, landform, landform position, production by lifeform, canopy cover by lifeform, ground cover, canopy cover and plant height by species, and geographic location coordinates (latitude, longitude). Location data were derived from both 1:24,000 topographic maps and global positioning systems (GPS). Accuracy for non-GPS plot positions is within $100 \mathrm{~m}$, and accuracy for GPS data ranges from 1 to $30 \mathrm{~m}$, depending on whether or not data were differentially corrected. The habitat type membership of each plot was determined based on floristic and abiotic characteristics following hierarchical dichotomous classification key structures developed for the study area by Jensen et al. (1992).

Table 1. List of raster-based biophysical predictor variables used in potential vegetation modeling.

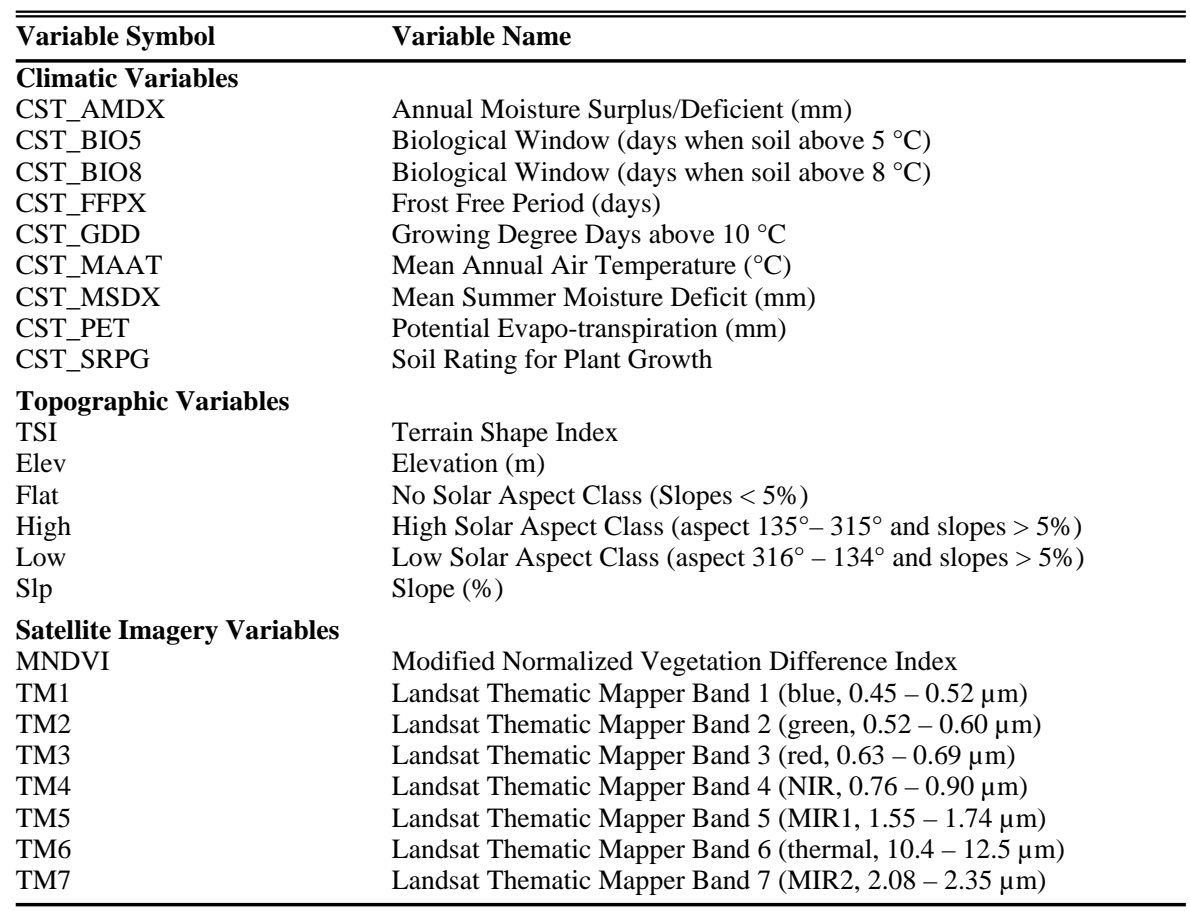

\section{Predictor variables}

A variety of raster-based climatic, topographic, and satellite imagery variables (Table 1) were associated with each field plot using ARC/INFO Geographic Information System (GIS) software for subsequent use as predictor variables in potential vegetation map construction. Nine climatic variables (Table 1) were calculated for a $200 \mathrm{~m}$ grid using a soil-climate interpolation model developed by the USDA, Natural Resource Conservation Service (NRCS) (Waltman et al. 1997). Primary input parameters for this model include: daily temperature and precipitation from local weather stations; soils data from USDA, NRCS, 1:250,000 STATSGO database; and topographic data from a $30 \mathrm{~m}$ digital elevation model. The original $200 \mathrm{~m}$ climatic grid was re-sampled to a $30 \mathrm{~m}$ resolution to relate climate variables with the other predictor variables used in this study.

Six topographic variables (Table 1) were calculated across the study area using a $30 \mathrm{~m}$ digital elevation model. Slope aspect was categorized into 3 classes: no aspect (slopes < 5\%), high solar aspect (135 to 315 degrees), and low solar aspect (316 to 134 degrees). A terrain shape index (TSI) was calculated following procedures described by $\mathrm{McNab}$ (1989), with positive values indicating concave topography (moisture accumulation) and negative values indicating convex topography (moisture depletion). 
Table 2. Habitat types denoted with a $(x)$ are those identified in the final discriminant analysis of potential vegetation environments stratified by lifeform (grasslands, shrublands, and woodlands) and subsection.

\begin{tabular}{|c|c|c|c|}
\hline Habitat Type & $\begin{array}{l}\text { Missouri } \\
\text { Plateau }\end{array}$ & $\begin{array}{l}\text { Missouri } \\
\text { Breaks }\end{array}$ & $\begin{array}{c}\text { Little } \\
\text { Missouri } \\
\text { Badlands }\end{array}$ \\
\hline \multicolumn{4}{|l|}{ Grassland Habitat Types } \\
\hline Agropyron smithii_Stipa comata & $X$ & $X$ & $\mathrm{X}$ \\
\hline Agropyron smithii_Stipa viridula & $\mathrm{X}$ & $\mathrm{X}$ & $\mathrm{X}$ \\
\hline Agropyron smithii_Stipa viridula-Bouteloua gracilis & $X$ & & $X$ \\
\hline \multicolumn{4}{|l|}{ Andropogon scoparius-Carex filifolia } \\
\hline \multicolumn{4}{|l|}{ Calamovilfa longifolia-Carex } \\
\hline Stipa comata-Carex filifolia & $\mathrm{X}$ & $\mathrm{X}$ & $X$ \\
\hline \multicolumn{4}{|l|}{ Shrubland Habitat Types } \\
\hline Artemisia cana-Agropyron smithii & $X$ & $\mathrm{X}$ & $\mathrm{X}$ \\
\hline Artemisia tridentata wyomingensis-Agropyron smithii & $X$ & & $\mathrm{X}$ \\
\hline Juniperus horizontalis-Andropogon scoparius & $X$ & $\mathrm{X}$ & $\mathrm{X}$ \\
\hline Rhus aromatica-Agropyron spicatum & & & $\mathrm{X}$ \\
\hline $\begin{array}{l}\text { Rhus aromatica-Muhlenbergia cuspidata } \\
\text { Sarcobatus vermiculatus-Agropyron smithii }\end{array}$ & $X$ & $X$ & $\mathrm{X}$ \\
\hline \multicolumn{4}{|l|}{ Woodland Habitat Types } \\
\hline Fraxinus pennsylvanica-Prunus virginiana & & & $\mathrm{X}$ \\
\hline Fraxinus pennsylvanica-Symphoricarpos occidentalis & $\mathrm{X}$ & & $\mathrm{X}$ \\
\hline $\begin{array}{l}\text { Fraxinus pennsylvanica/Ulmus americana-Prunus } \\
\text { virginiana }\end{array}$ & $\mathrm{X}$ & $\mathrm{X}$ & \\
\hline Juniperus scopulorum-Oryzopsis micrantha & & & $\mathrm{X}$ \\
\hline Populus deltoides-Juniperus scopulorum & & & $X$ \\
\hline Quercus macrocarpa-Prunus virginiana & $X$ & $X$ & \\
\hline
\end{tabular}

Two geographically distinct LANDSAT Thematic Mapper (TM) images were acquired for the Grasslands and processed for use in this study (Winne et al. Unpublished). Dates associated with these 2 images were June 1993 and July 1994, which were the most recent cloud-free image dates available for continuous coverage of the Grasslands. The 7 sensors of LANDSAT have proven useful to vegetation pattern mapping in previous research (Sabins 1987). In this study, these 7 spectral bands and a MNDVI value were assigned to a $30 \mathrm{~m}$ grid (Table 1). The MNDVI value was derived from spectral bands 3, 4, and 5 and has proven effective in distinguishing areas of high versus low biomass production in other studies (Sabins 1987).

\section{Potential vegetation mapping}

A potential vegetation map of habitat types for the Grasslands was developed through the following sequential steps: 1) identification of the habitat types to be mapped, 2) delineation of appropriate biophysical strata for modeling, and 3) multivariate statistical analysis and development of potential vegetation model rule sets by appropriate strata.

The 18 habitat types of the Grasslands described in previous classification efforts (Jensen et al. 1992) were initially considered for mapping in this study. Those types appropriate for mapping were identified by were selected because they effectively delineated major differences in climate, geology, and landform across the study area, yet they were large enough to contain sufficient numbers of plots for modeling. Although landtype association polygons (mapped at a 1:100,000 scale) represented more refined delineations of geoclimatic settings within the Grasslands, they were not used as strata in habitat type modeling because of insufficient plot sample sizes within individual mapping units.

Lifeform level maps of existing vegetation (i.e., grasslands, shrublands, and woodlands) developed previously for the Grasslands (Redmond et al. 1997) were used for secondary stratification within subsections during development of habitat type map rule sets. Because vegetation lifeform maps were highly accurate (i.e., over $90 \%$ accuracy) and most current disturbance processes within the Grasslands (e.g., herbivory, fire) do not change the lifeform conditions of a site, the use of lifeform maps as secondary strata in habitat type modeling was considered appropriate. Assumptions we made in selecting lifeform maps as a secondary strata included the fact that large stand consuming fires within the Grasslands have been effectively removed since homesteading began about 100 years ago (i.e., fire is currently not a major disturbance process). Additionally, herbivory by cattle rarely changes the lifeform status of a vegetation stand (i.e., most woodlands and shrublands maintain their overstory structures despite changes to understory species composition). The resultant 9 strata (3 subsections times 3 lifeforms) and the habitat types modeled within each of these 9 strata are presented in Table 2. An overview of the various GIS themes used in discriminant analysis modeling of potential vegetation at the habitat type level of ecological classification is presented in Fig. 2.

\section{Statistical Analysis} stratification process used in map preparation (Hutchinson 1982). Accordingly, a study area is commonly stratified by appropriate environmental variables prior to multivariate classification and mapping to reduce the potential number of vegetation classes and separate classes that are "spectrally similar" but geographically disjunct (Franklin 1995).

The initial stratification used to predict the distribution of habitat types in this study was based on the 3 subsections (Fig. 1) previously mapped within the Grasslands at a 1:500,000 scale (Nesser et al. 1997). These
The statistical analysis used in habitat type map construction included 2 steps. First, the stepwise multivariate analysis of variance test of the Statistical Package for the Social Sciences (SPSS) was used to determine which sets of predictor variables best discriminated between the habitat type membership of all field plots within the Grasslands. Second, variables that significantly $(\mathrm{P}<0.01)$ reduced Wilks' Lambda in the above stepwise MANOVA analysis were then used to compute Fisher 


\section{GIS Themes}
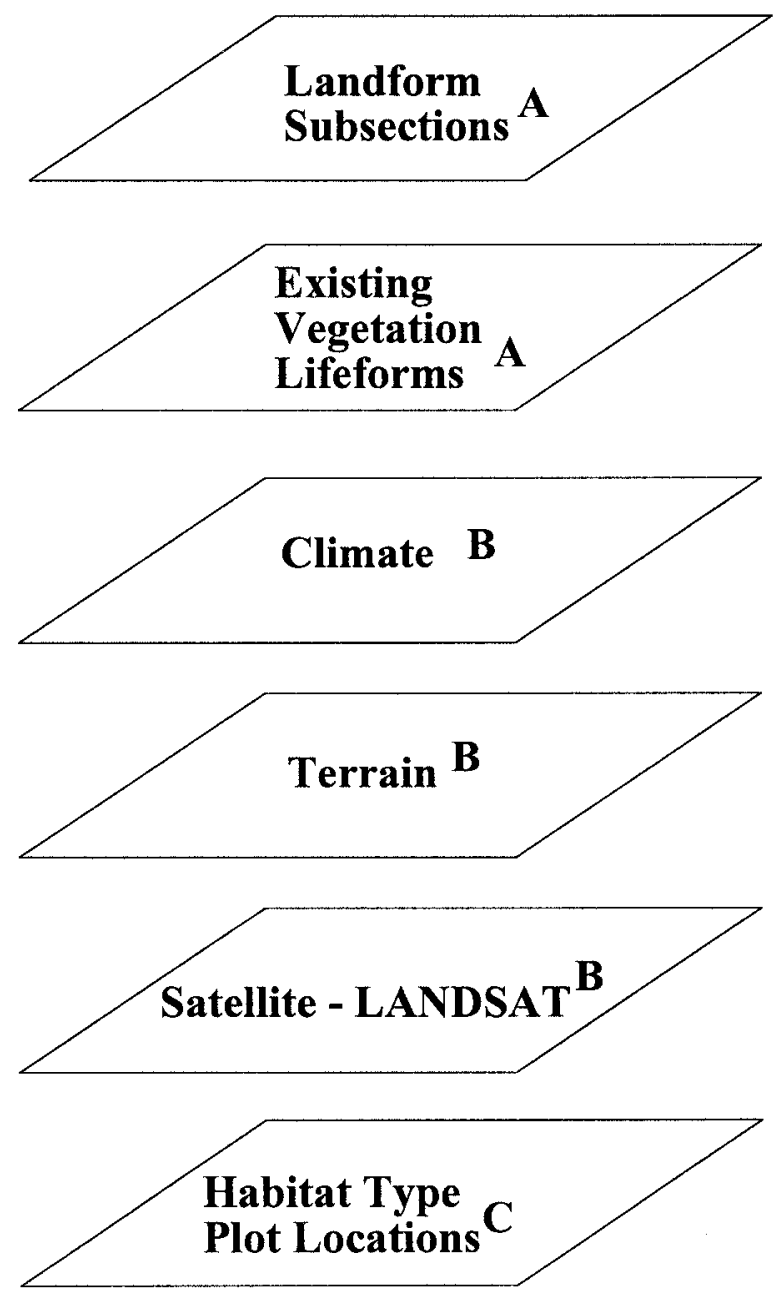

Fig. 2. The 6 basic Geographic Information System data themes used in discriminant analysis modeling of habitat types across the Little Missouri National Grasslands. (A = information used in model stratification, B = information used as independent "predictor" variables in model construction, and $\mathrm{C}=$ information used as dependent variables in model construction).

canonical discriminant functions for habitat type prediction by mapping strata. Assessment of the habitat type classification accuracy associated with each of the 9 discriminant analysis strata runs for the Grasslands was determined by a jackknife procedure (Norusis 1985). All plot data were used in developing our habitat type model. We did not split the dataset in our accuracy assessment, because the sample sizes associated with certain habitat types polygons. Clustering of similar polygons was based on Ward's (1963) clustering algorithm in these analyses.

\section{Results and Discussion}

\section{Accuracy assessment of the poten- tial vegetation map}

An example of our $30 \mathrm{~m}$ raster-based habitat type map of the Grasslands developed by discriminant analysis procedures is presented in Fig. 3. Classification accuracy of the complete projection is presented by subsection and lifeform in Table 3, and values are relatively high compared to previous predictions of vegetation pattern by similar discriminant analysis procedures (Franklin et al. 1989, Jensen et al. 1990, Franklin and Wilson 1991, Lowell 1991). Results of this analysis indicate that predictions of habitat types based on biophysical variables (Table 1) were consistently more accurate within woodland (70 to $100 \%$ ) as opposed to shrubland (62 to $100 \%$ ) and grassland (54 to $77 \%$ ) settings across all 3 subsections of the Grasslands. Conversely, accuracy for habitat type predictions across all lifeforms was highest in the Missouri Breaks, followed by the Missouri Plateau and the Little Missouri Badlands subsections (Table 3 ). These results support the use of environmental stratification for predictive vegetation mapping. Further support was offered by an initial discriminant analysis of habitat types across the Grasslands that was stratified by the 3 lifeforms described above but by only 1 geoclimatic setting (i.e., the Northern Great Plains section). Results of that analysis (DiBenedetto 1998) indicated a habitat type classification accuracy rate of only 20,32 , and $54 \%$, respectively, for grassland, shrubland, and woodland lifeforms across the study area. Stratification of Fisher discriminant mapping functions by subsections (geoclimatic settings) greatly improved the accuracy of predicted habitat type distributions in this study.

Significance of biophysical environment predictor variables in discriminating habitat type patterns

The climatic, topographic, and spectral variables listed in Table 1 were analyzed by a stepwise MANOVA to determine which variables best discriminated between the habitat type membership of field plots and, therefore, should be used in developing Fisher canonical discriminant functions for habitat type mapping. Results of this analysis are presented in Table 4, 


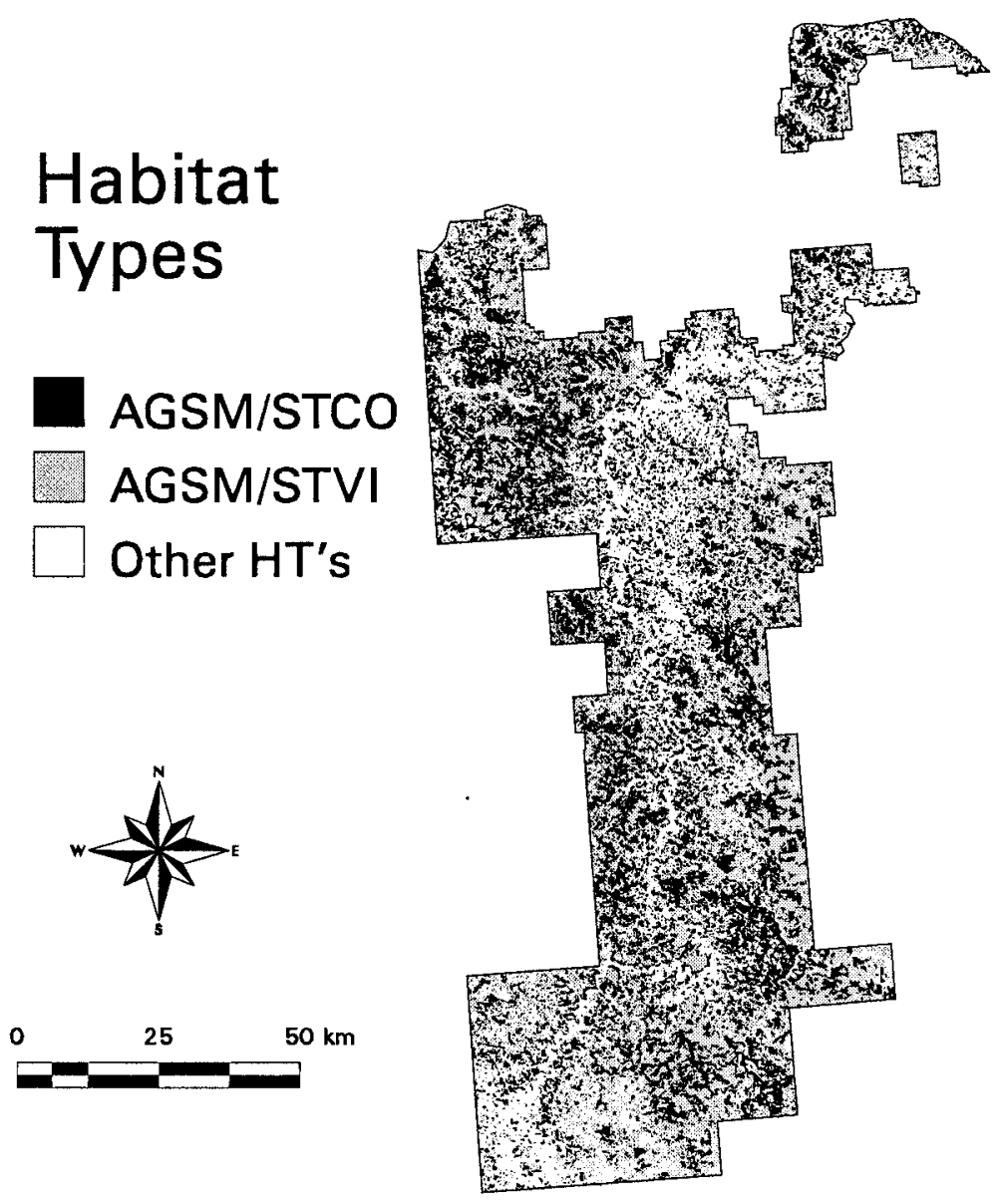

Fig. 3. A $30 \mathrm{~m}$ raster-based projection of 2 dominant grassland habitat types across the Little Missouri National Grasslands. $($ AGSM $=$ Agropyron smithii, STCO $=$ Stipa comata , and STVI = Stipa viridula .

which displays by subsection/lifeform strata, those predictor variables that significantly $(\mathrm{P}<0.01)$ reduced Wilks' Lambda and were, in turn, used in Fisher canonical discriminant function calculations.

An examination of the top 3 predictor variables within each column of Table 4 (i.e., those in bold print) suggests that subsections are useful strata in habitat type prediction because they partition the landscape into units that have different predictor variable relations at the lifeform level. For example, within the grassland habitat types, the top 3 predictor variables are different between each of the subsections studied. Variables CST_PET, Flat, and TM5 were the best predictors of grassland habitat types within the Missouri Plateau subsection; however, variables ELEV, CST_FFPX, and MNDVI were the best predictors in the Missouri Breaks subsection, and variables TSI, CST_MAAT, and TM6 were the best predictors in the Little Missouri Badlands subsection (Table 4). Shrubland habitat types exhibit this same relation, with different rankings for the top 3 predictor variables among subsection groupings. Only within the woodland habitat types did the top 3 predictor variables display some commonality between subsections (i.e., CST_PET and SLP).

Lifeform-based stratifications of the Grasslands were also useful in habitat type prediction because they effectively partitioned subsections into units that have different predictor variable relations. For example, within the Missouri Plateau subsection only the variables CST_PET and SLP were within the top 3 predictor variables across 2 or more lifeforms. group.
Similarly, only the variable CST_MAAT was shared as a top predictor between lifeforms within the Little Missouri Badlands subsection, and none of the top 3 predictor variables were shared between lifeforms within the Missouri Breaks subsection (Table 4). These results indicate that the environmental stratification process used in this predictive vegetation mapping study of the Grasslands (i.e., partitioning by subsection and existing vegetation lifeform settings) was effective in habitat type prediction as indicated by the classification accuracy values presented in Table 3 .

Consistently higher accuracy within woodlands, followed by shrublands and grasslands, across the 3 subsection strata (Table 3) suggests that the predictor variables used in model construction (Table 1) are reasonable indicators of available soil moisture. This interpretation is supported by previous habitat typing efforts within the Grasslands, in which all researchers concluded that woodlands occupied the most mesic sites, followed by shrublands and grasslands in decreasing order of available soil moisture (Hansen et al. 1984, Hirsh and Baker 1984, Girard et al. 1989, Jensen et al. 1992). Accordingly, it appears that available soil moisture is the primary factor influencing habitat type distribution across the Grasslands. A secondary factor considered important in determining habitat type distribution patterns across the Grasslands is available soil nutrients. This factor is associated with soil types; unfortunately, these were unavailable in digital format and could not be included in this study. Consequently, the broad-level subsection environments of the Grasslands (which were primarily mapped based on differences in landform and surface geology) were the best correlates for soil patterns and associated soil nutrient and waterholding capacities. Observed soil patterns across the Grasslands are most complex within the Little Missouri Badlands followed by the Missouri Plateau and Missouri Breaks

Table 3. Overall classification accuracy of Fisher canonical discriminant functions in predicting the habitat type membership of field plots by subsection and lifeform strata groupings. Accuracy is expressed as the percent of sites correctly predicted within each lifeform and subsection group. " $N$ " is the number of field plots used in modeling potential vegetation environments within each

\begin{tabular}{lccc}
\hline \hline Subsection & $\begin{array}{c}\text { Grassland } \\
\text { Habitat Types }\end{array}$ & $\begin{array}{c}\text { Shrubland Habitat } \\
\text { Types }\end{array}$ & $\begin{array}{c}\text { Woodland Habitat } \\
\text { Types }\end{array}$ \\
\hline & $(\%)$ & $(\%)$ & $(\%)$ \\
Missouri Plateau & $66 ; \mathrm{N}=86$ & $88 ; \mathrm{N}=57$ & $90 ; \mathrm{N}=31$ \\
Missouri Breaks & $77 ; \mathrm{N}=62$ & $100 ; \mathrm{N}=15$ & $100 ; \mathrm{N}=41$ \\
Little Missouri Badlands & $54 ; \mathrm{N}=97$ & $62 ; \mathrm{N}=69$ & $70 ; \mathrm{N}=158$ \\
\hline
\end{tabular}


Table 4. Stepwise multivariate analysis of variance listing of biophysical predictor variables that best discriminated between habitat types within the Little Missouri National Grasslands (All of the Wilk's Lambda values presented are highly significant $(P<0.01$ ), with larger numbers indicating those variables that best discriminated habitat type membership of field plots.) Results are presented by the nine subsection/lifeform strata groupings used in developing Fisher Canonical Discriminant Functions for habitat type mapping. Variable symbols are described in Table 1.

\begin{tabular}{|c|c|c|c|c|c|c|c|c|c|}
\hline & \multicolumn{3}{|c|}{ Missouri Plateau } & \multicolumn{3}{|c|}{ Missouri Breaks } & \multicolumn{3}{|c|}{ Little Missouri Badlands } \\
\hline & $\begin{array}{l}\text { Grass- } \\
\text { lands }\end{array}$ & $\begin{array}{l}\text { Shrub- } \\
\text { lands }\end{array}$ & $\begin{array}{l}\text { Wood- } \\
\text { lands }\end{array}$ & $\begin{array}{l}\text { Grass- } \\
\text { lands }\end{array}$ & $\begin{array}{c}\text { Shrub- } \\
\text { lands }\end{array}$ & $\begin{array}{l}\text { Wood- } \\
\text { lands }\end{array}$ & $\begin{array}{l}\text { Grass- } \\
\text { lands }\end{array}$ & $\begin{array}{l}\text { Shrub- } \\
\text { lands }\end{array}$ & $\begin{array}{l}\text { Wood- } \\
\text { lands }\end{array}$ \\
\hline \multicolumn{10}{|c|}{ Climate Variables } \\
\hline CST_AMDX & & 0.08 & & & 0.43 & & & 0.17 & 0.31 \\
\hline CST_BIO5 & & 0.11 & 0.05 & & 0.24 & & & 0.28 & \\
\hline CST_BIO8 & & 0.13 & & 0.24 & 0.03 & 0.12 & & 25 & \\
\hline CST_FFPX & 0.26 & 0.09 & & 0.36 & & & & & \\
\hline CST_GDD & 0.28 & & & & & 0.29 & & 0.32 & \\
\hline CST_MAAT & & & 0.12 & & & 0.11 & 0.76 & & 0.52 \\
\hline \multicolumn{10}{|l|}{ CST_MSDX } \\
\hline CST_PET & 0.42 & & 0.34 & & & 0.38 & & & \\
\hline CST_SRPG & 0.24 & 0.33 & & & & & 0.64 & & 0.29 \\
\hline \multicolumn{10}{|c|}{ Topographic Variables } \\
\hline TSI & 0.22 & & 0.21 & & & & 0.86 & 0.20 & \\
\hline Elev & & 0.26 & & 0.50 & & 0.14 & & & 0.35 \\
\hline Flat & 0.36 & & & & & & 0.56 & & \\
\hline High & & & 0.10 & & 0.06 . & & & 015 & \\
\hline Low & & 0.16 & & & & & & & \\
\hline Slp & & 0.56 & 0.50 & & & & & & 0.66 \\
\hline \multicolumn{10}{|c|}{ Satellite Imagery Variables } \\
\hline MNDVI & 0.30 & & 0.07 & 0.30 & & 0.19 & & & 0.44 \\
\hline TM1 & & 0.41 & & & & & & & \\
\hline TM2 & & & & & & 0.22 & & & \\
\hline TM3 & & & & 0.26 & & & 0.60 & & \\
\hline TM4 & & 0.20 & & & & & & & \\
\hline TM5 & 0.33 & & & & & & & 0.24 & 0.38 \\
\hline TM6 & & & & & & 0.16 & 0.69 & & \\
\hline TM7 & & & & & & & & 0.13 & \\
\hline
\end{tabular}

subsections. As a result, it is not surprising that habitat type predictions were poorest within the Little Missouri Badlands subsection (Table 3).

\section{Management applications}

The $30 \mathrm{~m}$ habitat type grid produced in this study provides a valuable base map for land use planning because it can be used to describe potentials for resource use, plant community succession pathways, and reference conditions associated with minimally altered ecosystem states (Jensen et al. 1991). Management, however, does not occur at the level of individual $30 \mathrm{~m}$ cells. Thus, to facilitate effective use of such base maps in land use planning, they can be associated to appropriately scaled mapping units such as ecological units or multiscale drainage basins depending on specific planning needs (Jensen et al. 1996, 1997). In the following discussion we present some examples of how the habitat type map developed in this study can be effectively generalized to different ecologically based mapping units for a variety of land management uses.

An example of a generalization of our habitat type map for general planning purposes is provided in Figure 4. This map was created by attributing the percent composition of predicted habitat types to each of the Natural Resource Conservation Service soil polygons within the Grasslands, and then clustering these polygons into similar groups based on habitat type composition. The 4 cluster groupings presented in Figure 4 provide a generalization of habitat type patterns across the Grasslands useful to broad-level planning efforts (e.g., forest plan revisions or regional scale ecological assessments). For example, Cluster 1 delineates broad valley bottom settings dominated by woodland and mesic shrub communities. Rolling prairie environments with a predominance of grassland habitat types are displayed in cluster groups 2 and 3 . The highly dissected badland environments of the Grasslands are represented by Cluster 4 .

Spatial projections of resource value potentials and condition are also facilitated by potential vegetation maps, and are illustrated for year long cattle-forage production potential in Figure 5a. This example was developed based on data collected for reference site (minimally disturbed) plots, which were summarized to describe various late seral plant community characteristics by habitat type (see Jensen et al. 1992). Weighted averages of these values based on habitat type composition within each soil polygon were then calculated by lifeform and across all lifeforms to develop the map presented in Figure 5a. The low, moderate, and high class ratings displayed in Figure 5a are based on average soil polygon values with high values indicating the upper $33 \%$ of polygons (>384 $\mathrm{kg} / \mathrm{ha}$ ), low values indicating the lower $33 \%$ of polygons $(<244 \mathrm{~kg} / \mathrm{ha})$ and moderate values indicating the middle $33 \%$ of polygons (244 to $384 \mathrm{~kg} / \mathrm{ha}$ ).

A similar summarization process to that described above was used in estimating the current condition of yearlong cattle-forage production across the Grasslands (Fig. 5b). In this example, ratings were based on the percent similarity between current (from existing vegetation maps) and reference conditions (from potential vegetation maps) and ranged between $24 \%$ and $136 \%$. The low, moderate, and high class ratings displayed in Figure 5b are also based on average soil polygon values; and the percent similarity to reference condition values associated with these three classes are $24 \%$ to $61 \%, 62 \%$ to $98 \%$, and 99 to 136 , respectively. Ratings of greater than $100 \%$ for forage condition occurred because some areas within the Grasslands have been converted from native prairies to crested wheatgrass communities (Agropyron cristatum (L.)(Gaertn.)), which commonly have higher forage production 


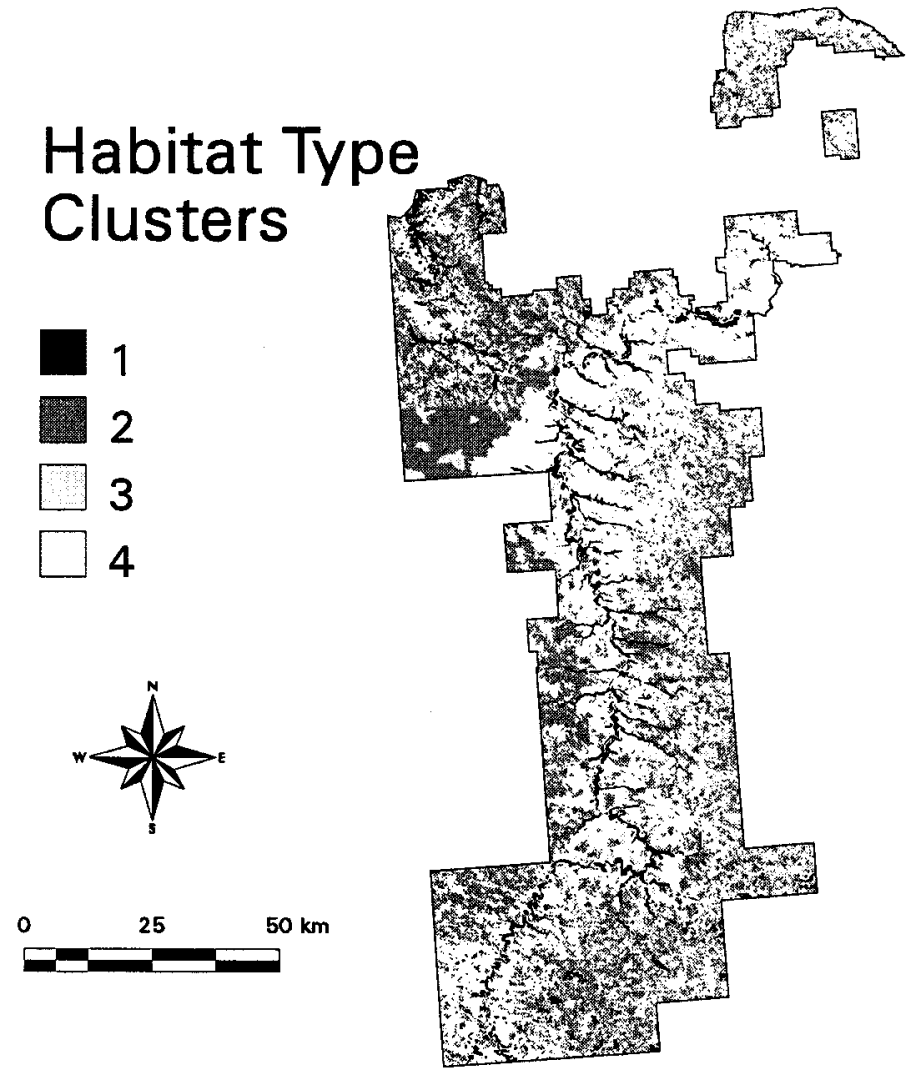

Fig. 4. Generalized habitat type cluster groupings of the Little Missouri National Grasslands appropriate to regional and subregional scale ecological assessments and land use planning. a) Site

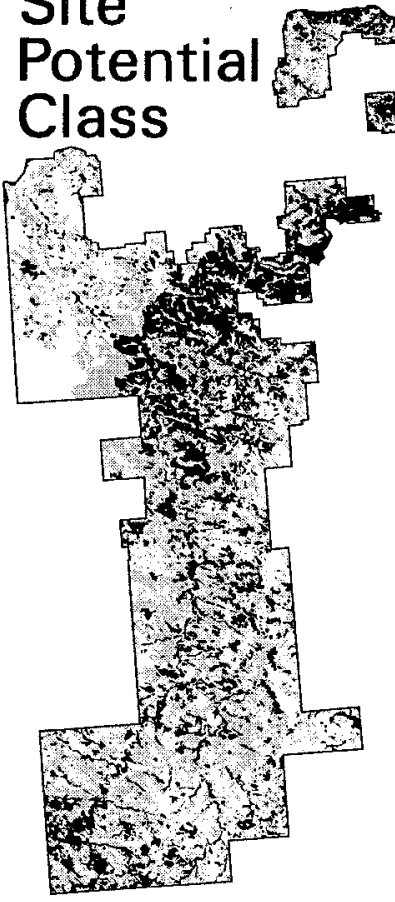

b) Current Condition Class

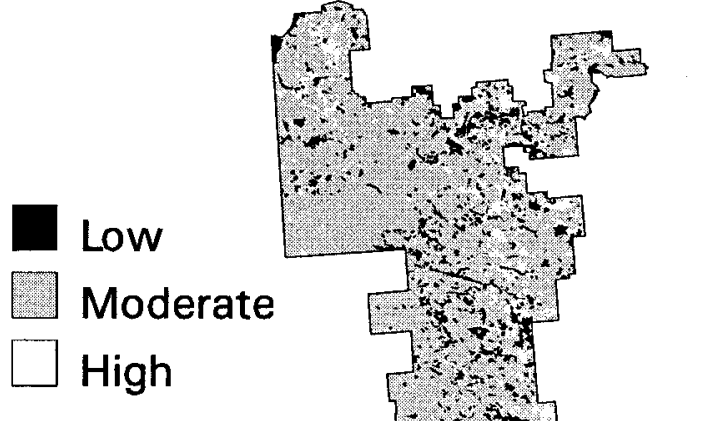

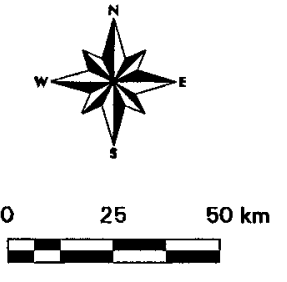

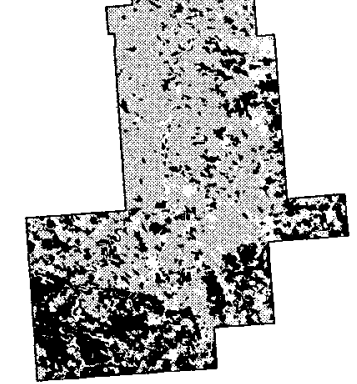

Fig. 5. Year long cattle forage production class ratings for the Little Missouri National Grasslands. ( $a=$ site potential ratings based on reference conditions, $b=$ current condition ratings based on the degree of similarity between existing and reference conditions) values than native reference communities. For a more complete discussion concerning the use of ecological classifications in broad-level assessments of rangeland health and condition, the reader is referred to Jensen et al. 2000.

\section{Conclusions}

The discriminant analysis procedure used to model potential vegetation environments in this study was very effective in predicting habitat types; however, the large number of observations (i.e., field plots) required in this type of analysis might limit its use in other areas. Depending on the number, spatial distribution, and quality of field plot data, as well as the types and spatial resolution of mapped predictor variables available for a study area, a variety of other techniques also can be used in predictive vegetation mapping (see Franklin 1995 for a thorough review). Examples of these other modeling approaches include: Boolean logic, simple regression, multiple regression, logic regression, classification trees, neural networks, simple rule-based methods, and fuzzy logic. Each of these methods have characteristic strengths and weaknesses and may or may not be appropriate to a particular mapping effort given data availability, software limitations, and the personal experience of the research analyst. Regardless of the approach used in predictive vegetation mapping, we offer the following key points that should be considered in future efforts:

- Ensure that the vegetation patterns to be predicted are appropriate given their characteristic range of landscape patch sizes and the grain size of the predictor variables used in modeling (e.g., grain should be 5 to 10 times smaller than average patch size).

- Stratification of a study area into more homogeneous environments greatly improves the performance of a predictive vegetation model.

- When possible, the biophysical variables considered for inclusion in a predictive vegetation model should be tested at multiple spatial scales to determine the appropriate grain size for such information. For example, climate interpolation models (Thornton et al. 1997, Waltman et al. 1997) can be run at $30 \mathrm{~m}, 90 \mathrm{~m}$, and $1 \mathrm{~km}$ resolution to access the spatial scale at which different climatic attributes influence the pattern of interest.

- Gradient-oriented field sampling (Austin and Heylingers 1991, Austin et al. 1994, 
Bourgeron et al. 1994) should be used in plot selection to facilitate direct testing of assumed relations between biophysical variables and vegetation patterns.

\section{Literature Cited}

Austin, M.P. and P.C. Heylingers. 1991. New approach to vegetation survey design: gradsect sampling. In: C. R. Margules and M.P. Austin, eds. Nature conservation: cost effective biological surveys and data analysis. Melbourne, Australia: CSIRO: 31-36.

Austin, M.P. and T.M. Smith. 1989. A new model for the continuum concept. Vegetatio. 83:35-47.

Austin, M.P., A.O. Nicholis, M.D. Doherty, and J.A. Meyers. 1994. Determining species response functions to an environmental gradient by means of a beta-function. J. Veg. Sci. 5 215-228.

Bailey, Robert G. 1995. Description of the ecoregions of the United States $2 \mathrm{~d}$ ed. rev. and expanded (1st ed. 1980). Misc. Publ. No. 1391 (rev.). U.S. Dept. of Agr., For. Serv. Washington, DC. 108p. with separate map at 1:7,500,000.

Bailey, R.G., M.E. Jensen, D.T. Cleland, and P.S. Bourgeron. 1994. Design and use of ecological mapping units. In: M.E. Jensen and P.S Bourgeron, eds. Ecosystem management: principles and applications: eastside forest ecosystem health assessment. PNW-GTR-318. U.S. Dept. of Agr., For. Serv., Pacific Northw. Res. Sta., Portland, Ore. 2:101-112.

Bourgeron, P.S., H.C. Humphries, and M.E. Jensen. 1994. General sampling design considerations for landscape evaluation. In: M.E. Jensen and P.S. Bourgeron, eds. Ecosystem management: principles and applications: eastside forest ecosystem health assessment. PNW-GTR-318. U.S. Dept. of Agr., For. Serv., Pacific Northw. Res. Sta., Portland, Ore. 2:109-120.

Cleland, D.T., P.E. Avers, W.H. McNab, M.E. Jensen, R.G. Bailey, T. King, and W.E. Russell. 1997. National hierarchical framework of ecological units. In: Mark S. Boyce and Alan Haney, eds. Ecosystem management: applications for sustainable forest and wildlife resources. Yale Univ. Press, New Haven and London: 181-200.

Daubenmire, R. 1968. Plant communities, a textbook of plant synecology. Harper and Row Publishers, New York. 300 p.

DiBenedetto, Jeff P. 1998. Hierarchical relations of ecological classification and mapping systems within mixed grass prairie. M.S. thesis Montana State Univ., Bozeman, Mont.

Franklin, Janet. 1995. Predictive vegetation mapping: geographic modelling of biospatial patterns in relation to environmental gradients. Progress in Physical Geography. 19(4): 474-499.

Franklin, S.E. and B.A. Wilson. 1991. Vegetation mapping and change detection using SPOT MLA and LANDSAT imagery in Kluane National Park. Can. J. of Remote Sens. 17:2-17.

Franklin, S.E., D.R. Peddle, and J.E. Moulton. 1989. Spectral/geomorphometric discrimination and mapping of terraIn: a study in Gros Morne National Park. Can. J. Remote Sens. 15: 28-42.
Girard, M.M., H. Geotz, and A.J. Bjugstad. 1989. Native woodland habitat types of southwestern North Dakota. Res. Pap. 281. U.S. Dept. of Agr., For. Serv., Rocky Mountain Forest and Range Exp. Sta., Fort Collins, Colo. $36 \mathrm{p}$.

Hansen, P.L., G.R. Hoffman, and A.J. Bjugstad. 1984. The vegetation of Theodore Roosevelt National Park, North Dakota: a habitat type classification. U.S. Dept. of Agr. For. Serv., Rocky Mountain Forest and Range Exp. Sta., Ft. Collins, Colo. 35 p.

Hironaka, M., M.A. Fosbert, and A.H. Winward. 1983. Sagebrush-grass habitat types of southern Idaho. Bull. 35. Univ. of Idaho, For. Wildlife and Range Exp. Sta., Moscow, Ida.

Hirsh, K.J. and W.T. Baker. 1984. Classification of grasslands and shrublands in southwestern North Dakota. In: Proceedings, North Dakota Academy of Science; April 1984. Grand Forks, N.D. The Academy. Vol. 38. 82 p.

Hutchinson, C.F. 1982. Techniques for combining LANDSAT and ancillary data for digital classification improvement. Photogramm. Eng. Remote Sensing. 48:123-130.

Jensen, M.E., J.D. DriBenedetto, and F. Heisner. 1992. An ecological classification for the Little Missouri National Grasslands. U.S. Dept. of Agr., Northern Region, Missoula, Mont.

Jensen, M.E., L.S. Peck, and M.V. Wilson. 1988. A sagebrush community type classification for mountainous northeastern Nevada rangelands. Great Basin Nat. 48:422-433.

Jensen, M.E., G.H. Simonson, and M. Dosskey. 1990. Correlation between soils and sagebrush-dominated plant communities of northeastern Nevada. Soil Sci. Soc. of Amer. J. 54:902-910.

Jensen, Mark E., Cecilia H. McNicoll, and Martin Prather. 1991. Application of ecological classification to environmental effects analysis. J. of Env. Qual. 20:24-30.

Jensen, Mark E., Patrick Bourgeron, Richard Everett, and Iris Goodman. 1996. Ecosystem management: a landscape ecology perspective. J. Amer. Water Res. Assoc. 32:203-216.

Jensen, Mark, Iris Goodman, Ken Brewer, Tom Frost, Gary Ford, and John Nesser. 1997. Biophysical environments of the basin. In: Thomas M. Quigley, and Sylvia J. Arbelbide, tech. eds. An assessment of ecosystem components in the Interior Columbia Basin and portions of the Klamath and Great Basins: Volume 1. PNW-GTR-405. U.S. Dept. of Agr., For. Serv, Pacific Northw. Res. Stat., Portland, Ore. 335p.

Jensen, Mark E., Roland L. Redmond, Jeff P. BiBenedetto, Patrick S. Bourgeron and Iris A. Goodman. 2000. Application of ecological classification and predictive vegetation modeling to broad-level assessments of ecosystem health. Environ. Monitoring and Assess. 64:197-212.

Kuchler, A.W. 1964. Potential natural vegetation of the conterminous United States. American Geographical Society, Spec. Publ. No. 36. 116 p.

Lowell, K.E. 1991. Utilizing discriminant function analysis with a geographical information system to model ecological succession spatially. Int. J. Geogr. Infor. Sys. 5:175-191.

McNab, W.H. 1989. Terrain shape index: quantifying effect of minor landforms on tree height. Forest Science. 35: 91-104.
Meuggler, W.F. and W.L. Stewart. 1980. Grassland and shrubland habitat types of western Montana. Gen. Tech. Rep. INT-66. Ogden, Utah: U.S. Dept. of Agr., For. Serv., Intermountain Forest and Range Exp. Sta. 154 p.

Mueller-Dombois, D., and H. Ellenberg. 1974. Aims and methods of vegetation ecology. John Wiley and Sons, New York. 547 p.

Nesser, John A., Gary L. Ford, C. Lee Maynard, and Deborah S. Page-Dumroese. 1997. Ecological units of the Northern Region: subsections. INT-GTR-369. U.S. Dept. of Agr., For. Serv., Intermountain Res. Sta., Ogden, Utah. 88 p.

Norusis, M.J. 1985. Statistical package for the social sciences. SPSS, Inc., Chicago, Ill.

Pfister, R.D., B.L. Kovalchick, J.B. Waide, and R.C. Presby. 1977. Forest habitat types of Montana. INT-GTR-34. U.S. Dept. of Agr., For. Serv., Intermountain Forest and Range Exp. Sta., Ogden, Utah. 174 p.

Redmond, R.L., J.C. Winne, T.P. Tady, M. Thornton, J. Troutwine, and Z. Ma. 1997. Existing vegetation and land cover of the Little Missouri, Grand River, and Sheyenne National Grasslands. Final Report, Contract \#53-034304-000012, submitted to U.S. Dept. of Agr., For. Serv., Northern Regional Office. Montana Coop. Wildl. Res. Lab, The Univ. of Montana, Missoula, Mont. 174p.

RISC. 1983. Guidelines and terminology of range inventories and monitoring. Report of Range Inventory Standardization Committee. Denver, Colo.: Soc. Range Manage. 28 p.

Sabins, F.F. 1987. Remote sensing, principles and interpretation, 2nd edition. W.H. Freeman and Company. New York. 449 p.

Shiflet, T.N. 1973. Range sites and soils in the United States. In: Arid shrublands. Proc. $3^{\text {rd }}$ Workshop of the U.S./Australian Rangeland Panel, Tucson, Ariz.. Denver, Colo.: Soc. Range Manage: 26-33.

Soil Survey Staff. 1975. Soil Taxonomy. U.S. Dept. of Agr., Hand. 436, U.S. Gov. Print. Office, Washington, DC.

Thornton, P.E., S.W. Running, and Michael A. White. 1997. Generating surfaces of daily meteorological variables over large regions of complex terrain. J. Hydro. 190: 214-251.

USDA, FS. 1988. Ecosystem classification handbook, chapter 4-ecodata sampling methods. Northern Region, Missoula, Mont.

USDA, FS. 1991. Ecological classification. In: Ecological classification and inventory handbook, FSH 2090.11. Washington, D.C.

Waltman, W.J., E.J. Ciolkosz, M.J. Mausbach, M.D. Svoda, D.A. Miller, and P.J. Kolb. 1997. Soil climate regimes of Pennsylvania. The Pennsylvania State Univ. Agr. Exp. Sta. Bull. No. 873. Univ. Park, Penn.

Ward, J.H. 1963. Hierarchical groupings to optimize an objective function. J. Amer. Statist. Assoc. 58: 236-244.

Whitman, W.C. 1978. Analysis of grassland vegetation on selected key areas in southwestern North Dakota. A Report on a Project of the North Dakota Regional Environmental Assessment Program Contract No. 7-01-2. Dept. of Botany, North Dakota State Univ., Fargo, N.D. 199 p. 